Economics Development Analysis Journal 6(1)(2017)

\title{
Analysis of Efficiency of Government Expenditure In Health Sector in Central Java Province in 2012-2014
}

\author{
Eka Dian Puspitasari ${ }^{1 凶}$, Amin Pujiati $^{2}$
}

Department of Development Economics, Faculty of Economics, Semarang State University

\begin{tabular}{ll}
\hline Article Info & $\begin{array}{l}\text { Abstract } \\
\text { Article History: }\end{array}$ \\
$\begin{array}{l}\text { Received October 2017 } \\
\text { Accepted December 2017 } \\
\text { Published February 2017 }\end{array}$ & $\begin{array}{l}\text { Health is one of the important factors in the success of the economic development in a country. The } \\
\text { Government has managed the health budgets of at least ten percent of the total of the available local } \\
\text { government budget. However, the amount of health budget has not been balanced yet by the optimal } \\
\text { achievement of health status. This research aims at analyzing the technical efficiency level of the } \\
\text { expenditure cost and the health service system and the target of improvement in order to achieve the } \\
\text { efficiency in Central Java province in 2012-2014. This research uses Data Envelopment Analysis } \\
\text { Keywords: }\end{array}$ \\
$\begin{array}{l}\text { Efficiency, Expenditure } \\
\text { of Health Budget, Data } \\
\text { Envelopment Analysis. }\end{array}$ & $\begin{array}{l}\text { variable, uses facilities and health services as the intermediate output variable, and uses the health } \\
\text { status as the outcome variable. The assumption used is: Variable Return to Scale (VRS) and the } \\
\text { output oriented model. The results of research that use the DEA method show that with the cost } \\
\text { technical efficiency there are only five regencies/cities (14.3\%) that have achieved an efficiency of } \\
\text { 100 percent. While with the system technical efficiency there are only eleven regencies/cities (31.4\%) } \\
\text { that have achieved an efficient condition. This means, most regencies/cities in Central Java Province } \\
\text { have not still efficient yet in the use of expenditure of health sector budget. }\end{array}$
\end{tabular}

\begin{tabular}{l}
\hline Corresponding Author: \\
Journal's Room, L Building, FE UNNES Sekaran Gunungpati \\
Semarang 50229, Indonesia \\
E-mail: dianpuspitasari@gmail.com
\end{tabular}

E-mail: dianpuspitasari@gmail.com 


\section{INTRODUCTION}

Economic development is increasing not only seen from the aspect of quantity, but also rather far more important from the aspect of quality. The aspect of quality is manifested in qualified human resources. Improving the quality of human resources is determined by the health status, the education, and the income level per capita (Mulyadi, 2003: 2-3). Health is one important factor in realizing the qualified human resources. According to the Acts No. 36 of 2009, health is a healthy state, both physically, mentally, spiritually and socially that enables everyone to live productively socially and economically. The purpose of health development that is in line with the Millennium Development Goals (MDGs) goal is to optimally improve the public health status. Atmawikarta (2005) stated that one factor that affects the high low level of achievement of public health status is how much financing is for the health sector.

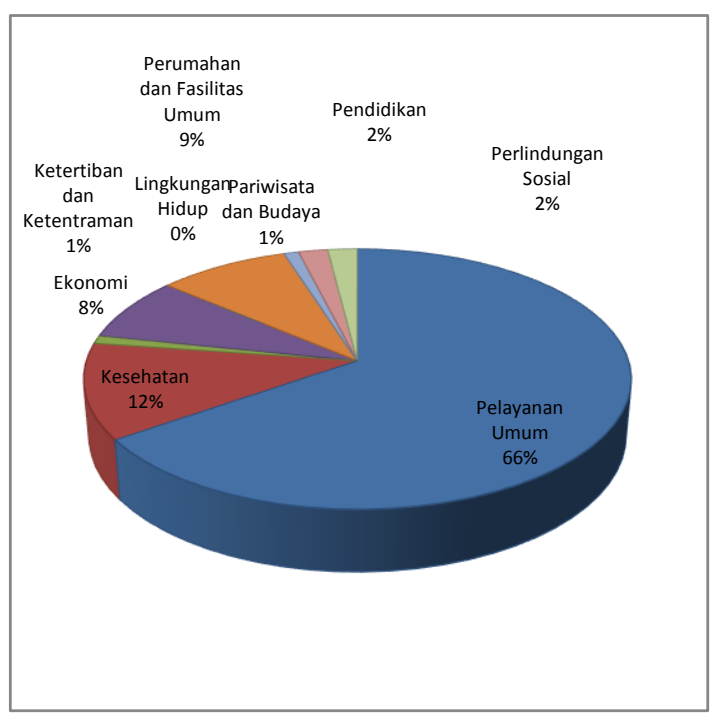

Figure 1. Diagram of Proportion of the Local Budget According to the Function of the Central Java Provincial Government in 2014.

Source : The Local Budget of Regencies/Cities in Central Java Provincial Government in 2015

The government has determined the health budget for the central government at least $5 \%$ of the state budget outside the salary, while for the province and regency/city governments at least $10 \%$ of the state budget outside of salary. Central Java Province has an increase in health expenditure annually during 2012-2014.

Even in 2014 the health expenditure in Central Java Province has the third rank in Indonesia under the Provinces of DKI Jakarta and East Java Province, while West Sulawesi Province has the lowest health expenditure. The following is a diagram of the proportion of the local budget according to the function of Central Java Provincial Government.

Based on the figure 1, it can be seen that the total recapitulation of Central Java Provincial Local Budget in 2014 amounted Rp 13,997 billion rupiah. Health expenditure was at the

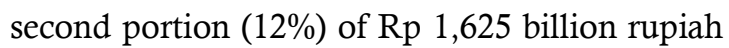
under the general service expenditure amounted Rp 9,234 billion rupiah (66\%). This means that the Central Java Provincial Government has been in accordance with the determination of allocation of local health budget at least $10 \%$ of the total Local Budget outside of salary.

The implementation of regional autonomy encourages the regions to rule and manage the affairs and finances of their own regions. It is expected that the local government know more about the conditions and needs of the region. Efficiency in the government expenditure is defined as every rupiah spent by the local government produces the people's optimal welfare (Kurnia, 2006). The data from the Directorate General of Fiscal Balance in the Local Budget recapitulation shows that in general the regencies/cities in Central Java Province have a trend of health expenditure that tends to increase in 2012-2014. A total of 14 regencies/cities experienced a growth in health expenditure with an average growth above the provincial average. It is assumed that the increasing health trend every year should be able to improve the people's optimal health status in Central Java Province.

The most sensitive indicators and the one that have been agreed nationally as the measure of the health status of a region are Infant Mortality Rate (IMR), Maternal Mortality Rate 
(MMR), and Life Expectancy Rate (LER). The data from the Health Office in Central Java Province shows that the average IMR of 35 regencies/cities in 2012-2014 amounted 10.78 per 1000 live births. A total of 15 regencies/cities still have the higher IMR than the provincial average of IMR. The highest average of IMR is in Rembang Regency with 15.87 per 1000 live births, and the lowest is in Surakarta Regency with an achievement of IMR 4.11 per 1000 live birth.

Furthermore, for the MMR indicator, the number of MMR cases during 2012-2014 recorded that 14 regencies/cities still exceeds the average of MMR of Central Java Province of 119.16 per 100,000 live births. The highest average of MMR is in Pekalongan Regency with 202.22 of MMR per 100,000 live births. The lowest MMR is in Surakarta with 53.31 of MMR per 100,000 live births. The regions that have an increase in MMR during the research period are Cilacap, Sukoharjo, Kudus, Semarang, Pekalongan, Tegal, Brebes, and Semarang. If seen from the achievement of LER indicator during the research period, it has increased, but despite increasing every year, there are 18 regencies/cities which average of LER are still below the provincial average of 72.1 years old. The highest LER was reached by Karanganyar Regency with the achievement of age of 73.9 years old, the lowest was reached by Brebes Regency with LER achievement of 68.2 years old.

In general, most regencies/cities in Central Java Province still experience the high maternal and infant mortality rates, which can be seen from the amount of regencies/ cities that still have the mortality rates above the provincial average. The level of achievement of the public health status indicators seen from IMR, MMR and LER in Central Java Province in 2012-2014 should still be improved. Based on the above problems, this research aims at analyzing the technical efficiency of the cost and the expenditure system of the health sector and services and how the improvement targets can be taken by the regencies/cities to achieve the efficiency.

\section{RESEARCH METHOD}

Types and Source of Data, the data used is secondary data obtained from the Directorate General of Fiscal Balance, Central Java Provincial Health Office, and the Central Bureau of Statistics (BPS) of Central Java Province. It includes the data on the local budget expenditure on health sector, the data on facility and health service indicator including the number of Public Health Center; the number of midwives; and the number of beds available in the hospitals, and also the data on public health status indicators including the Infant Mortality Rate (IMR), the Maternal Mortality Rate (MMR), and the Life Expectancy Rate (AHH). The type of data used is data from 35 regencies/cities in the Central Java Province in 2012-2014.

Variables of Research, the variables used to measure the relative efficiency in this research use the input and output variables. This research uses three variables those are input variable, intermediate output variable, and output variable. Intermediate output variable is intended to accommodate the indirect relationship between the input and output variables. The input variable used is the government expenditure on health sector in proxy of health expenditure per capita. The intermediate output variable is an indicator of health facilities and services including the ratio of Public Health Center per 100,000 population, the ratio of the number of midwives per 100,000 population, and the ratio of the number of beds available in the hospitals per 100,000 population. While the output variable is an indicator of public health status including the Infant Mortality Rate (IMR) in proxy of Life Birth Rate (LBR), the Maternal Mortality Rate (MMR) in proxy of Maternity Giving Birth Rate (MGBR), and the Life Expectancy Rate (LER).

Method of Data Analysis, this research uses Data Envelopment Analysis (DEA) method for the relative efficiency of an Economic Activity Unit (EAU) in multi-input and multioutput condition. Besides, DEA is capable to accommodate the units of different input and output variables (Rusydiana, 2013). DEA is able 
to measure the relative efficiency level of the government expenditure on health sector with EAU of 35 regencies/cities in Central Java Province.

So it will determine which regencies/cities that have been efficient and not efficient in the use of health expenditure. A company is said to be technically efficient when generating a maximum output with certain resources (Amirillah, 2014).

DEA assumes that each EAU will choose a weight maximizing the total weighted output and input. To calculate the relative efficiency of the government expenditure on health sector in Central Java Province the following linear programming is used.

Maximizing

With constraint limits:
1. $\sum_{r=1}^{s} U_{r k} Y_{r k}-\sum_{i=k}^{m} V_{i k} X_{i k} \leq 0 ; k=$ $1,2, \ldots, n, \ldots$
2. $\sum_{i=k}^{m} V_{i k} X_{i k}=$
3. $U_{r k} \geq 0 ; r=1,2, \ldots, s$.
4. $V_{i k} \geq 0 ; i=1,2, \ldots, m$

The description of the above equation is explained as follows $\mathrm{Zk}$ is Regencies/cities observed, $\mathrm{K}$ is Regencies/cities assessed in the analysis of 35 regencies/cities, $Y_{\text {rk }}$ is Number of outputs r produced by UKE $\mathrm{k}, X_{I k}$ is $\mathrm{Nu}$ mber of inputs I used by UKE $\mathrm{k}, \mathrm{s}$ is Number of outputs generated (services, health facilities and health status), $\mathrm{m}$ is Number of inputs used (district health spending), $U_{r k}$ is Weighted weight of the output $\mathrm{r}$ produced per UKE $\mathrm{k}, \mathrm{V}_{\text {ik }}$ is Weighted weight of input i generated per UKE $\mathrm{k}$.

The model assumption used in this research is the output orientation, which means that the amount of output can be increased proportionally without changing the number of inputs used.

So this efficiency analysis will generate a technical efficiency of cost and system. And it also uses the approach of Variable Return to Scale (VRS) with the assumption that the ratio of input and output addition is not the same. In the health sector, the addition of the proportion of inputs may not necessarily increase the proportion of output with the same value, because there are other factors influencing such as education level, public awareness, environmental conditions, and many others.

In order to ensure the level of achievement of the technical efficiency of health sector, it needs to classify the criteria of efficiency level measure those are perfect/optimum efficiency, high efficiency, medium efficiency, low efficiency, and no efficiency (Fathoni, 2016).

Table 1. Criteria of Level Measure of Technical Efficiency of Health Expenditure in Central Java Province.

\begin{tabular}{ll}
\hline Criteria of Efficiency & $\begin{array}{l}\text { Value } \\
\text { Efficiency } \\
\text { (percent) }\end{array}$ \\
\hline Perfect/Optimum & 100 \\
High & $81-99$ \\
Medium & $60-80$ \\
Low & $41-59$ \\
Not Efficient & $\leq 40$ \\
\hline
\end{tabular}

Source : Fathoni, 2016.

\section{RESULTS AND DISCUSSIONN}

Technical Efficiency of Health Expenditure Cost in Central Java Province, The value of cost technical efficiency is derived from the comparison between the input variable in the form of health expenditure per capita of each regency/city government and the intermediate output variable in the form of available health facilities and service indicators.

The intermediate output variable describes how much the local government effort is in providing the adequate health facilities and services for the public.

The assumption used is the Variable Return to Scale, which means that the amount of health expenditure issued by the local government is able to produce the number of outputs of health facilities and services with unequal quantities. Furthermore, the model used is the output orientation (output oriented).

The calculation result of technical efficiency value of health expenditure in Central Java Province as follow : 
Table 2. Calculation Result of Cost Technical Efficiency of Health Sector Expenditure in Central Java Province in 2012-2014.

\begin{tabular}{|c|c|c|c|c|}
\hline \multirow{2}{*}{ Regencies/Cities } & \multicolumn{3}{|c|}{ Cost Technical Efficiency } & \multirow{2}{*}{$\begin{array}{l}\text { Average of } \\
\text { Efficiency }\end{array}$} \\
\hline & 2012 & 2013 & 2014 & \\
\hline Cilacap Regency & 70.62 & 100.00 & 100.00 & 90.21 \\
\hline Banyumas Regency & 65.32 & 68.88 & 61.14 & 65.11 \\
\hline Purbalingga Regency & 61.70 & 60.05 & 55.69 & 59.15 \\
\hline Banjarnegara Regency & 100.00 & 100.00 & 84.79 & 94.93 \\
\hline Kebumen Regency & 99.82 & 85.54 & 94.68 & 93.35 \\
\hline Purworejo Regency & 82.40 & 83.21 & 100.00 & 88.54 \\
\hline Wonosobo Regency & 74.53 & 71.98 & 76.53 & 74.35 \\
\hline Magelang Regency & 65.84 & 68.13 & 100.00 & 77.99 \\
\hline Boyolali Regency & 71.66 & 69.56 & 70.64 & 70.62 \\
\hline Klaten Regency & 100.00 & 100.00 & 100.00 & 100.00 \\
\hline Sukoharjo Regency & 96.38 & 89.69 & 98.79 & 94.95 \\
\hline Wonogiri Regency & 100.00 & 100.00 & 100.00 & 100.00 \\
\hline Karanganyar Regency & 83.49 & 78.05 & 86.52 & 82.69 \\
\hline Sragen Regency & 100.00 & 98.12 & 100.00 & 99.37 \\
\hline Grobogan Regency & 76.31 & 85.58 & 84.68 & 82.19 \\
\hline Blora Regency & 72.55 & 72.01 & 77.36 & 73.97 \\
\hline Rembang Regency & 100.00 & 93.81 & 85.32 & 93.04 \\
\hline Pati Regency & 71.49 & 71.70 & 79.86 & 74.35 \\
\hline Kudus Regency & 77.84 & 75.17 & 81.24 & 78.08 \\
\hline Jepara Regency & 78.33 & 72.03 & 63.19 & 71.18 \\
\hline Demak Regency & 61.15 & 61.89 & 67.59 & 63.54 \\
\hline Semarang Regency & 67.57 & 65.05 & 67.66 & 66.76 \\
\hline Temanggung Regency & 90.28 & 88.22 & 100.00 & 92.83 \\
\hline Kendal Regency & 88.87 & 81.93 & 69.63 & 80.14 \\
\hline Batang Regency & 89.02 & 82.15 & 86.36 & 85.84 \\
\hline Pekalongan Regency & 83.59 & 79.92 & 73.61 & 79.04 \\
\hline Pemalang Regency & 84.83 & 82.98 & 100.00 & 89.27 \\
\hline Tegal Regency & 68.00 & 64.16 & 66.45 & 66.20 \\
\hline Brebes Regency & 70.45 & 59.34 & 73.50 & 67.76 \\
\hline Magelang City & 100.00 & 100.00 & 100.00 & 100.00 \\
\hline Surakarta City & 100.00 & 100.00 & 100.00 & 100.00 \\
\hline Salatiga City & 83.96 & 84.71 & 83.89 & 84.19 \\
\hline Semarang City & 100.00 & 100.00 & 100.00 & 100.00 \\
\hline Pekalongan City & 86.29 & 83.76 & 97.08 & 89.04 \\
\hline Tegal City & 75.68 & 75.66 & 78.07 & 76.47 \\
\hline
\end{tabular}

Source : Secondary Data, processed.

Table 2 shows that in 2012 there were only eight regencies/cities that have achieved 100 percent of perfect efficiency value. In 2013 the number of regencies/cities that could achieve 100 percent of efficiency declined to seven regions.
The region experiencing the decline is Cilacap Regency. In 2014 the regencies/cities that could achieve 100 percent of efficiency increased again into eleven regions those are Cilacap, Purworejo, Magelang, Klaten, 
Wonogiri, Sragen, Temanggung, Pemalang, Magelang, Surakarta, and Semarang.

During 2012-2014, the regions that have achieved the perfect technical efficiency cost on average only five regencies/cities (14.3 percent) of Klaten, Wonogiri, Magelang, Surakarta, and Semarang. The lowest efficiency is Purbalingga Regency. The regions that have achieved 100 percent of perfect cost technical efficiency indicate that those regions have been efficient in the use of inputs in the form of local government health expenditure allocated for the provision of basic health facilities and services consisting of the provision of the number of Public Health Center, the number of midwives, and the number of beds available in the hospital, assuming that the additional inputs in the form of costs used to finance health expenditure have resulted in the additional output. While the regions that have not achieved 100 percent of efficiency scores, indicate that those regions have not been optimal in the use of health sector expenditure.

Technical Efficiency of Health Services System, The technical efficiency of this system is generated by giving inputs in the form of basic health facilities and services consisting of the ratio of the number of Public Health Center, the ratio of the number of midwives, and the ratio of the number of beds available in the hospital in comparison with the output variable in the form of public health status indicator including the Infant Mortality Rate (IMR) in proxy the Life Birth Rate (LBR), the Maternal Mortality Rate (MMR) in proxy the Maternity Giving Birth Rate (MGBR), and the Life Expectancy Rate LER) assuming that the large inputs of basic health facilities and services provided by the local government are able to generate the number of public health status with unequal amounts (Variable Return to Scale), the output orientation model. The calculation result of technical efficiency value of health care system in Central Java Province as follows:

Table 3 shows that in 2012 there were only thirteen regencies/cities that have achieved 100 percent of perfect system efficiency. In 2013, the regions that achieved 100 percent of perfect efficiency increased to seventeen regions. In 2014 it increased to twenty regencies/cities that were able to achieve 100 percent of perfect efficiency. During 2012-2014, the average achievement of system technical efficiency was only eleven regencies/cities (31.4 percent) that were capable of achieving 100 percent of perfect efficiency. Similar to the cost technical efficiency, the regions that have not reached 100 percent of efficiency indicate that those regions are not yet optimal in pursuing the basic facilities and health services to achieve the optimal public health status. In other words, the policy of increasing the number of health facilities and services in inefficient regions, if not followed by the improvement of the health system, will affect the level of public health status.

Target of Input and Output Improvement to Achieve Efficient Conditions, besides being able to find the relative efficiency value of each EAU, the efficiency of DEA is also capable of making scenarios of input and output improvements for the inefficiency through the identification of too much input and too low output. The following shows the calculation result of target of input and output variables that are not efficient to achieve efficiency.

Based on the calculation of improvement targets, it shows that from 35 districts / cities in Central Java Province, in the regions that have achieved 100 percent of perfect efficiency both cost technical efficiency and system technical efficiency there is no target value and potential improvement that must be changed by the local government of the regencies/cities concerned. Table 4 above describes the improvement targets for some regencies/cities that have achieved the cost technical efficiency as well as the system technical efficiency, and those that have been efficient in both technical efficiencies.

The regencies/cities that have cost technical efficiency do not necessarily have system technical efficiency, and vice versa. Purbalingga Regency has achieved 100 percent of perfect technical condition, but has the low achievement value of low cost technical efficiency that is 59.15 percent. 
Table 3. Calculation Result of System Technical Efficiency of Health Sector in Central Java Province in 2012-2014

\begin{tabular}{llllc}
\hline Regencies/Cities & \multicolumn{2}{l}{ System } & Technical Efficiency & $\begin{array}{c}\text { Average } \\
\text { Efficiency }\end{array}$ \\
\cline { 2 - 4 } Cilacap Regency & 2012 & 2013 & 2014 & 99.61 \\
\cline { 2 - 4 } Banyumas Regency & 99.62 & 99.64 & 99.57 & 99.99 \\
Purbalingga Regency & 99.64 & 100.00 & 100.00 & 99.50 \\
Banjarnegara & & & 100.00 & \\
Regency & 99.15 & 99.47 & 99.87 & 99.50 \\
Kebumen Regency & 99.78 & 99.85 & 99.62 & 99.75 \\
Purworejo Regency & 99.43 & 99.62 & 99.59 & 99.55 \\
Wonosobo Regency & 99.37 & 99.76 & 99.72 & 99.62 \\
Magelang Regency & 100.00 & 100.00 & 100.00 & 100.00 \\
Boyolali Regency & 99.47 & 99.90 & 99.75 & 99.71 \\
Klaten Regency & 99.70 & 99.69 & 99.98 & 99.79 \\
Sukoharjo Regency & 99.59 & 99.39 & 100.00 & 99.66 \\
Wonogiri Regency & 99.15 & 99.92 & 100.00 & 99.69 \\
Karanganyar Regency & 99.83 & 100.00 & 100.00 & 99.94 \\
Sragen Regency & 100.00 & 100.00 & 99.81 & 99.94 \\
Grobogan Regency & 99.41 & 99.45 & 98.55 & 99.14 \\
Blora Regency & 99.75 & 99.72 & 99.36 & 99.61 \\
Rembang Regency & 99.58 & 99.53 & 100.00 & 99.70 \\
Pati Regency & 100.00 & 100.00 & 100.00 & 100.00 \\
Kudus Regency & 99.86 & 99.94 & 100.00 & 99.93 \\
Jepara Regency & 100.00 & 100.00 & 100.00 & 100.00 \\
Demak Regency & 100.00 & 100.00 & 100.00 & 100.00 \\
Semarang Regency & 100.00 & 100.00 & 100.00 & 100.00 \\
Temanggung Regency & 100.00 & 100.00 & 99.43 & 99.81 \\
Kendal Regency & 99.50 & 99.44 & 100.00 & 99.65 \\
Batang Regency & 99.60 & 99.45 & 99.56 & 99.54 \\
Pekalongan Regency & 99.66 & 99.91 & 99.92 & 99.83 \\
Pemalang Regency & 100.00 & 100.00 & 100.00 & 100.00 \\
Tegal Regency & 100.00 & 100.00 & 100.00 & 100.00 \\
Brebes Regency & 100.00 & 100.00 & 100.00 & 100.00 \\
Magelang City & 99.49 & 100.00 & 99.43 & 99.64 \\
Surakarta City & 99.77 & 100.00 & 100.00 & 99.92 \\
Salatiga City & 100.00 & 100.00 & 100.00 & 100.00 \\
Semarang City & 100.00 & 100.00 & 100.00 & 100.00 \\
Pekalongan City & 100.00 & 100.00 & 99.99 & 100.00 \\
Tegal City & 99.73 & 99.64 & 100.00 & 99.79 \\
\hline
\end{tabular}

Source : Secondary Data, processed. 
Eka Dian Puspitasari \& Amin Pujiati/ Economics Development Analysis Journal 6 (1) (2017

Table 4. Target of Improvement of Input and Output Variables in Achieving Cost Technical Efficiency and System Technical Efficiency of Health Sector Expenditure in

Central Java Province in 2014

\begin{tabular}{|c|c|c|c|c|}
\hline Regencies/Cities & Variables & Actual & Target & $\begin{array}{l}\text { Potential } \\
\text { Improvement }\end{array}$ \\
\hline \multirow[t]{12}{*}{ Klaten } & \multicolumn{4}{|l|}{ Cost Technical Efficiency } \\
\hline & $\begin{array}{l}\text { - Health Expenditure } \\
+ \text { Ratio of Public Health }\end{array}$ & 148106.47 & 148106.47 & - \\
\hline & Center & 13.00 & 13.00 & - \\
\hline & + Ratio of Midwives & 51.04 & 51.04 & - \\
\hline & + Ratio of Beds & 88.21 & 88.21 & \\
\hline & \multicolumn{4}{|c|}{ System Technical Efficiency } \\
\hline & $\begin{array}{l}\text { - Ratio of Public Health } \\
\text { Center }\end{array}$ & 13.00 & 12.35 & $(05.01)$ \\
\hline & - Ratio of Midwives & 51.04 & 50.30 & $(01.44)$ \\
\hline & - Ratio of Beds & 88.21 & 88.21 & - \\
\hline & $\begin{array}{l}\text { + Life Birth Rate } \\
+ \text { Maternity Giving Birth }\end{array}$ & 996.07 & 996.31 & - \\
\hline & Rate & 107237.07 & 108558.46 & 01.23 \\
\hline & + Life Expectancy Rate & 76.54 & 76.56 & 00.02 \\
\hline \multirow[t]{12}{*}{ Wonogiri } & \multicolumn{4}{|l|}{ Cost Technical Efficiency } \\
\hline & $\begin{array}{l}\text { - Health Expenditure } \\
+ \text { Ratio of Public Health }\end{array}$ & 200649.97 & 200649.97 & - \\
\hline & Center & 22.31 & 22.31 & - \\
\hline & + Ratio of Midwives & 33.83 & 33.83 & - \\
\hline & + Ratio of Beds & 78.13 & 78.13 & - \\
\hline & \multicolumn{4}{|c|}{ System Technical Efficiency } \\
\hline & $\begin{array}{l}\text { - Ratio of Public Health } \\
\text { Center }\end{array}$ & 22,31 & 22,31 & - \\
\hline & - Ratio of Midwives & 33,83 & 33,83 & - \\
\hline & - Ratio of Beds & 78,13 & 78,13 & - \\
\hline & $\begin{array}{l}\text { + Life Birth Rate } \\
+ \text { Maternity Giving Birth }\end{array}$ & 995,54 & 995,54 & - \\
\hline & Rate & 115376,04 & 115376,04 & - \\
\hline & + Life Expectancy Rate & 75,84 & 75,84 & - \\
\hline \multirow[t]{11}{*}{ Purbalingga } & \multicolumn{4}{|l|}{ Cost Technical Efficiency } \\
\hline & - Health Expenditure & 208052.41 & 208052.41 & - \\
\hline & + Ratio of Public Health & 9.11 & 16.36 & 79.56 \\
\hline & Center & 32.95 & 59.16 & 79.56 \\
\hline & $\begin{array}{l}\text { + Ratio of Midwives } \\
\text { + Ratio of Beds } \\
\text { System Technical Efficiency }\end{array}$ & 47.12 & 84.61 & 79.56 \\
\hline & $\begin{array}{l}\text { - Ratio of Public Health } \\
\text { Center }\end{array}$ & 9.11 & 911 & - \\
\hline & - Ratio of Midwives & 32.95 & 32.95 & - \\
\hline & - Ratio of Beds & 47.12 & 47.12 & - \\
\hline & + Life Birth Rate & 995.14 & 995.14 & - \\
\hline & $\begin{array}{l}\text { + Maternity Giving Birth } \\
\text { Rate }\end{array}$ & 109609.93 & 109609.93 & - \\
\hline & + Life Expectancy Rate & 72.80 & 72.80 & \\
\hline
\end{tabular}

Source : Secondary Data, processed. 
Thus, the policy of Purbalingga Government that needs to be pursued is having more orientation on achieving the cost technical efficiency. So the improvement targets must be conducted is to increase the output target of health facilities and services in the form of the ratio of the number of Public Health Center from the actual number of 9.11 to 16.36 units per 100,000 population, the ratio of the number of midwives from the actual number of 32.95 to 59.16 per 100,000 population, and the ratio of the number of beds from 47.12 to 84.61 units per 100,000 population.

Based on the calculation result of improvement targets of the cost and system technical efficiency according to the regencies/cities in Central Java Province in 20122014, it can be seen that the severity that occurs in the cost technical efficiency is still in the criteria of moderate efficiency with an efficiency value of 60-80 percent, in contrast to the system technical efficiency, which efficiency value is within the high efficiency criteria of 81-99 percent. Thus, the calculation of improvement targets of the cost technical efficiency is to optimize the budget management. However, the policies adopted do not reduce the health sector budget but emphasize on the optimization of outputs those are the ratio of the number of Public Health Center, the ratio of the number of midwives, and the ratio of the number of beds available in the hospital.

This research is similar to the research conducted by Gunarson (2008) and Verhoeven (2007), which indicated that in the regions studied, the health sector expenditure used is also inefficient, which means that that government expenditure is not allocated optimally yet. Another research in line with this research is Indriati's (2011) that explored the efficiency of health sector expenditure in Sumbawa regency, in which the result showed that the cost and system technical efficiency that happened in some districts studied also varied and generally there were still many regions that were not efficient yet.

\section{CONCLUSION}

The acquisition of technical efficiency levels both the cost technical efficiency and the system technical efficiency in Central Java Province is still inefficient in the use of health sector expenditure. The achievement of technical efficiency level in Central Java Province is still in the criteria of high efficiency achievement between 81-99 percent. It needs to have the improvement targets for the input and output variables to achieve efficiency in the use of health expenditure.

\section{REFERENCES}

Afonso, Antonio., Schuknecht, Ludger., Tanzi, Vito. (2005). Public sector efficiency: An international comparison. Public Choice Vol. 123 (3-4) pp 321-347.

Amirillah, A. (2014). Efisiensi Perbankan Syariah Di Indonesia. Jejak: Jurnal Ekonomi Dan Kebijakan, $7(2)$. doi:http://dx.doi.org/10.15294/jejak.v7i2.38 95

Bose, Niloy., Haque, M. Emranul., Osborn, Denise R., (2007). Public Expenditure And Economic Growth: A Disaggregated Analysis For Developing Countries. The Mancherster School Vol. 75 (5) pp 533-556.

Direktorat Jenderal Perimbangan Keuangan, Data APBD Tahun Berjalan, http://www.dipk.depkeu.go.id/. (04 Februari 2016).

Fathoni, A. (2016). Analisis Efisiensi Ekonomi Industri Tekstil Dan Produk Tekstil Provinsi Jawa Tengah Tahun 2005-2011. Economics Development Analysis Journal, 5(1). Doi:Http://Dx.Doi.Org/10.15294/Edaj.V5i1 .10779

Gupta, Sanjeev., Verhoeven. (2001). The efficiency of government expenditure: experiences from Africa. Journal of Policy Modeling Vol 23 (4) pp. 433-367.

Indriati, Neneng Erlina. 2014. Analisis Efisien Belanja Daerah di Kabupaten Sumbawa (Studi Kasus Bidang Pendidikan dan Kesehatan). Dalam Jurnal Ekonomi Studi Pembangunan. 6 (2): 192205

Javarov dan Gunnarson. 2008. Government Spending on Health Care and Education in Croatia: Efficiency and Reform Options. IMF Working Paper, WP/08/136. 
Eka Dian Puspitasari \& Amin Pujiati/ Economics Development Analysis Journal 6 (1) (2017

Kurnia. 2006. Model Pengukuran Kinerja dan Efisiensi Sektor Publik Metode Free Disposable Hull (FDH). Dalam Jurnal Ekonomi Pembangunan. 11 (2): 1-20.

Mulyadi. 2003. Ekonomi Sumber Daya Manusia dalam Perpsektif Pembangunan. Jakarta : PT RajaGrafindo Persada.

Rusydiana, Aam Slamet. 2013. Mengukur Tingkat Efisiensi dengan Data Envelopment Analysis. Bogor : Smart Publishing.

Undang-Undang Republik Indonesia No. 36 Tahun 2009 tentang Kesehatan. 